\title{
JENNIFER HUNT
}

Yale University

\section{Hours Reductions as Work-Sharing}

OVER THE PAST century, annual hours per worker have been falling in industrialized countries. This fall could be influenced by labor supply, through an income effect, as workers have become richer, but it could also be influenced by labor demand, as the increasingly skill-intensive nature of jobs has reduced the number of hours for which workers can maintain high productivity. For most of the period, the motivation expressed by those campaigning for shorter hours has been to improve health and safety, or simply to improve the quality of life. When concern about the level of unemployment has been high, however, the declared motivation has sometimes been "work-sharing," which is the hope (or conviction) that a reduction in hours per worker will spread the available work around and hence increase employment. This motivation was important during the Great Depression in the United States and other countries, and it has resurfaced in Europe since unemployment began to rise around 1975 .

Supporters of work-sharing have usually focused on reductions in the standard weekly hours of full-time workers, that is, the number of hours beyond which an overtime premium must be paid. However, hours reductions sometimes take the form of fewer shifts per month or increased vacation time. In the United States, the overtime premium has been seen as the most relevant tool for achieving reductions. The Netherlands is unusual, in that increasing part-time work has been seen as a means of reducing hours. The debate is currently most topical in

I thank John Evans of the Organisation for Economic Co-operation and Development for advice and Lawrence Katz for comments. I thank Andrew Pearlman for assistance in preparing the data. 
France and Italy, where the governments have presented work-sharing proposals in 1998. Both plans seek to raise employment by cutting standard hours to thirty-five per week within four years. In western Germany, the debate was largely carried out in the 1980s and reductions in the standard week justified on work-sharing grounds are ongoing.

In this paper I focus on work-sharing through the reduction of hours of full-time workers, with emphasis on the contrasting experiences of the United States, Germany, and France. ${ }^{1}$ Popular confidence in the ability of work-sharing to increase employment is based on the idea that the amount of work that needs to be done is fixed. However, as I show below, if a reduction in hours implies an increase in the marginal cost of production at the original level of output, optimal output will fall (the scale effect), tending to reduce demand for inputs. Higher marginal labor costs will also cause substitution away from labor and toward other inputs. Thus both total hours of work and employment could fall, even if the hourly wage remains unchanged. The effect on actual hours per worker is also ambiguous. Another important consideration is associated movement in the real hourly wage. Although one might imagine that leisure must be "bought"' with a lower hourly wage, unions involved in work-sharing have campaigned for increases in the hourly wage to "compensate" for the lost hours. Such a rise in the real hourly wage would reduce the likelihood of employment gains.

Existing evidence suggests that employment declines as a result of work-sharing, raising the possibility that output has likewise fallen. In the case of Germany, the unions appear to have been successful in negotiating increases in the real hourly wage, which has contributed both to the overall trend of rising real wages and to the reduction in employment in work-sharing sectors. New analysis presented below indicates that reductions in the standard hours of German men have reduced the labor supply of their wives.

The industrial relations literature suggests that in most countries hours reductions are initiated by workers, and that union strength may be an important determinant of which countries experience the largest reductions. However, workers in different countries may desire different numbers of hours, due to differing wage levels or distributions or differing

1. Eastern Germany has higher standard hours than western Germany and its labor market issues are different. All data and discussions in this paper refer to western Germany. 
unemployment rates. The number of hours desired by employers may also vary in different countries, due to variation in industrial (and hence technological) composition, in fixed per worker costs, and in overtime premiums. Such differences could affect the degree to which employers resist workers' attempts to reduce hours. Evidence for Germany presented below shows that work-sharing has not been particularly effective in bringing actual hours in line with desired hours. This suggests that the unions may have been motivated by concerns about employment, as claimed, or by a desire to increase wages more than would have been possible except under the guise of work-sharing. The possibility that hours were reduced because employers wanted them to be seems unlikely, given the continued public opposition of employers to work-sharing.

I begin by summarizing statistics on hours and employment for several countries, and then describe work-sharing in the United States, Germany, and France. I then discuss existing theoretical and empirical knowledge about work-sharing and present some evidence on the effect of work-sharing on German labor supply. I examine possible reasons for differences across countries in levels of and changes in full-time hours and present evidence on the effect of German work-sharing on the convergence of actual and desired hours.

\section{International Comparison of Hours}

Figure 1 shows trends in annual hours per worker (that is, total hours worked in the year divided by average employment) for various countries, based on data from the Organisation for Economic Co-operation and Development (OECD). Since the method of calculation varies considerably by country, the levels of hours are not comparable and only trends are shown. Rather than changes in employment rates, these numbers in general reflect changes in overtime hours, standard hours, shorttime work, and vacation time, as well as changes in the proportion of part-time workers and in their hours. ${ }^{2}$

2. See Organisation for Economic Co-operation and Development, Employment Outlook, various issues, for detailed notes on calculation methods, and in a few cases, changes in these methods. Even trends may not be fully comparable: for example, for the Netherlands, hours do not include overtime; and some countries include the selfemployed while others do not. The French data are produced within the national accounts 

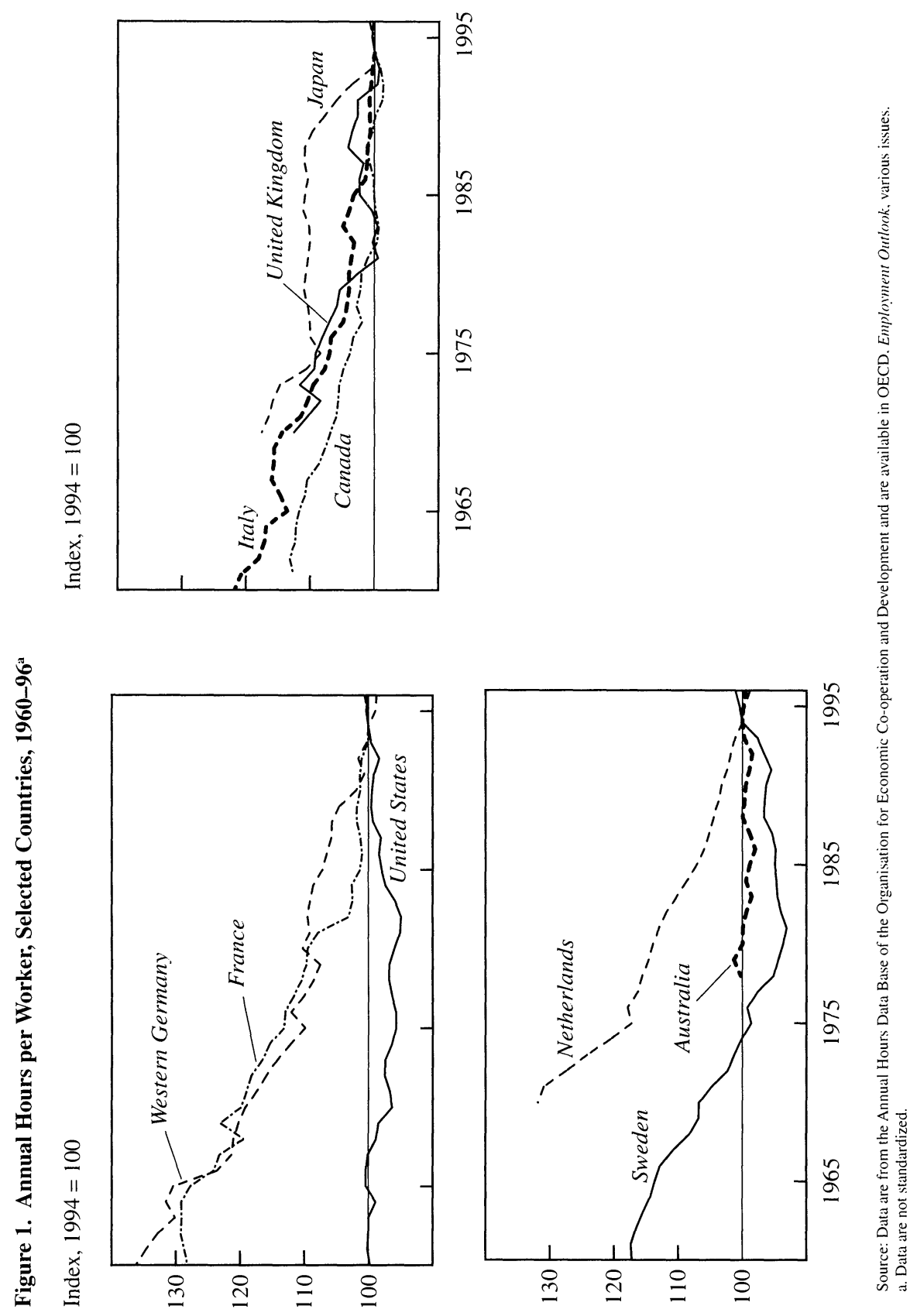
The most striking point about the figure is that the United States differs from almost all other countries: in 1996 annual hours were the same as they had been in 1960, after a fairly small dip, while in all other countries except Australia, they fell by at least 10 percent over the periods for which OECD data are available. ${ }^{3}$ The largest declines were in western Germany, France, and the Netherlands.

The statistics presented in figure 1 can be converted into an index of annual hours per person above the age of compulsory schooling by using employment-to-population ratios provided by the Bureau of Labor Statistics (BLS). The employment-to-population ratios themselves are shown in figure 2. In the United States, this ratio was relatively low in 1960 , but began an upward trend in the late 1970s, driven by increased female employment rates. The United States currently has the highest employment rate of the countries pictured. Canada and the Netherlands are the only other countries where employment rates did not fall. Figure 3 shows the product of the employment rates and annual hours per worker, or annual hours per adult. As a result of the rising American employment rate, these plots show greater disparity between the United States and other countries, except Canada and the Netherlands, than is seen in figure 1 . Hours per adult have increased by more than 10 percent in the United States since 1960, according to this measure.

The trends in figure 1 are somewhat misleading if one is interested in hours reductions related to work-sharing, since for some countries they are strongly influenced by increases in part-time work. Linda Bell and Richard Freeman calculate what proportion of the hours reductions for 1983-94 from the OECD data may be attributed to a rising share of parttime workers. ${ }^{4}$ For the Netherlands and the United Kingdom, the rising

framework. The German data are based on establishment survey estimates of weekly full-time hours, adjusted for factors such as public holidays, sickness, overtime, and part-time work. The United States data originate from data on hours paid for nonfarm employees from Bureau of Labor Statistics (BLS), Current Employment Statistics, which are converted to hours worked using the Hours at Work survey, and then extended to the whole economy using the Current Population Survey (both surveys by the BLS). Note that comparable statistics on levels of hours since 1982 for countries in the European Union are available from Eurostat.

3. Other sources of data for Australia suggest that hours fell by 5 to 6 percent during the period 1948-82; Dawkins and Baker (1994, p. 51).

4. Bell and Freeman (1996). Bell (1995) shows that if the OECD data on hours levels are taken at face value, little of the intercountry variation is due to variation in part-time share; rather, it appears mostly due to variation in full-time hours. 


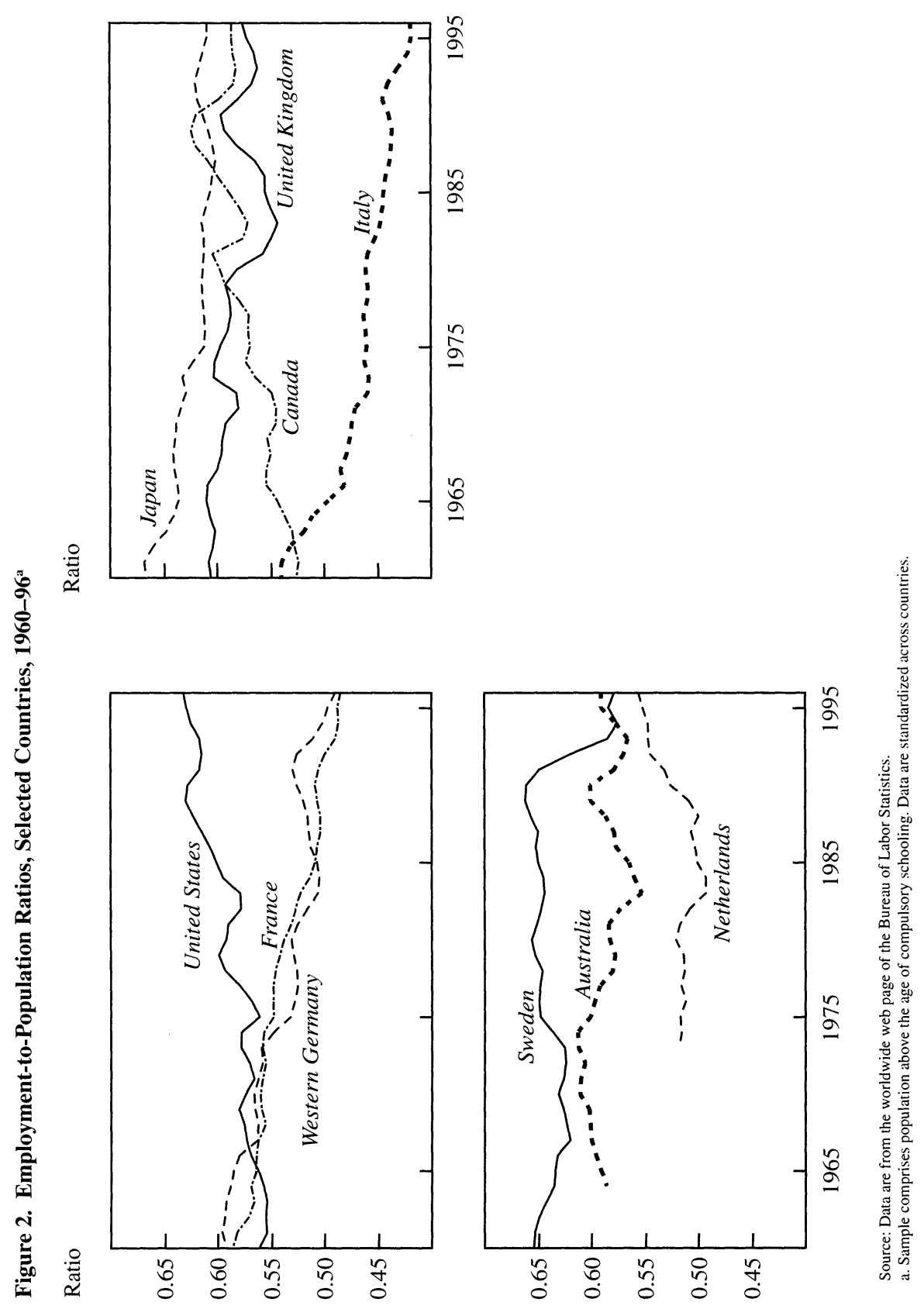



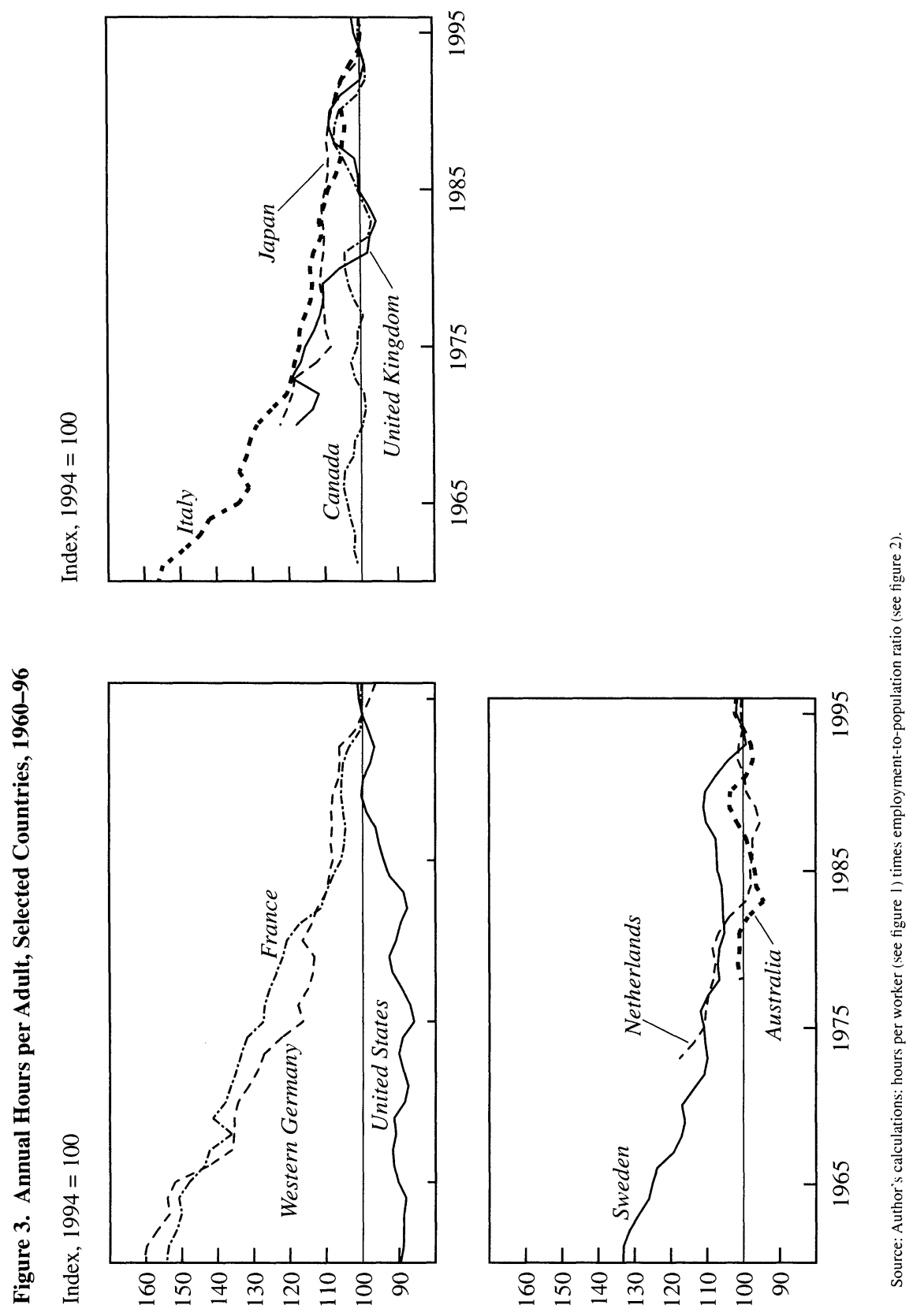
share of part-time workers substantially overpredicts the fall in hours, for France it fully explains the fall, while for Germany and Italy it explains about a quarter to a third of the fall, with changes in hours of full-timers being the dominant effect. ${ }^{5}$ Thus it is clear that data on full-time workers are required.

The only internationally comparable data on full-time hours that are not limited to the countries of the European Union pertain to blue collar workers in manufacturing. The German employers' federation, the Bundesvereinigung der Deutschen Arbeitgeberverbände, has calculated standard annual hours based on standard weekly hours, vacation days, and holidays since 1984. These numbers therefore do not account for overtime or short-time, sickness, or dual job holding. Annual hours for 1995 and their decomposition, as well as the changes in annual hours since 1984, are shown in table 1 . The countries are ordered by 1995 annual hours, with western Germany at the top (1,602 hours) and Japan, 22 percent higher in hours, at the bottom $(1,957)$. Germany has the shortest standard work week and the largest number of vacation days, both of which contribute to its very low annual hours. The United States is a low outlier in terms of vacation days, and this accounts for its high annual hours.

Japan and Germany have had the largest falls in hours since 1984, with reductions of 9 to 10 percent. There has been essentially no reduction in Sweden or the United States. France is in the middle of the table, in terms of level of hours, and had one of the smaller reductions between 1984 and 1995. In fact, for purposes of comparison, the period before 1983 in France is of interest, as there has been little reduction since 1982, when there was a legislated reduction in working time (discussed further below). Between 1973 and 1983, part-time employment rose from 5.9 to 9.6 percent in France, while in Germany it rose from 10.1 to 12.6 percent. Since the declines in overall annual hours per worker in figure 1 are similar for the two countries, this indicates that full-time hours probably fell faster in Germany than in France over the same period. ${ }^{6}$

5. Organisation for Economic Co-operation and Development, "Flexibility of Working Hours: Latest Trends and Policy Initiatives,' Employment Outlook, 1998 (forthcoming) provides a very similar decomposition.

6. The part-time data come from Organisation for Economic Co-operation and De- 


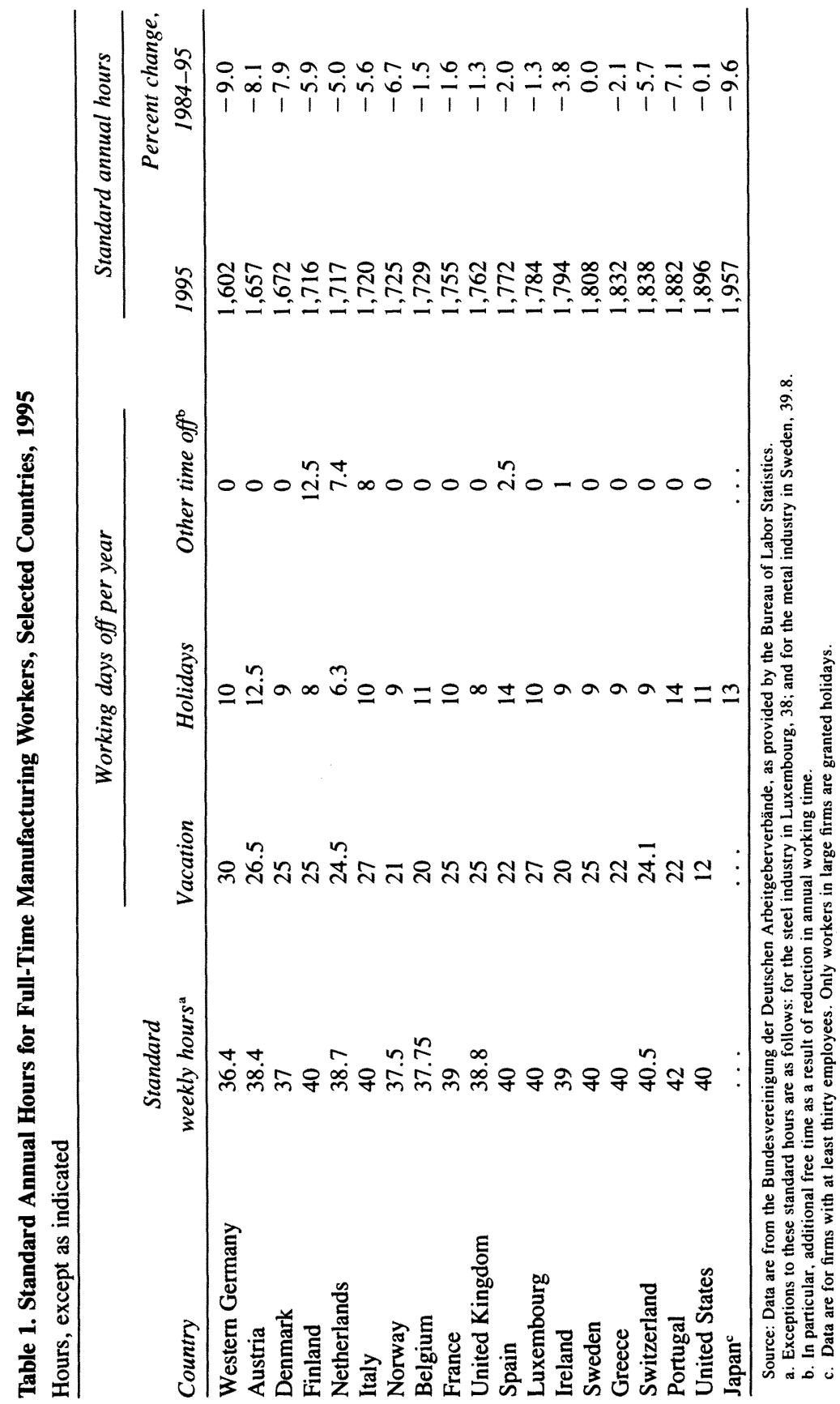



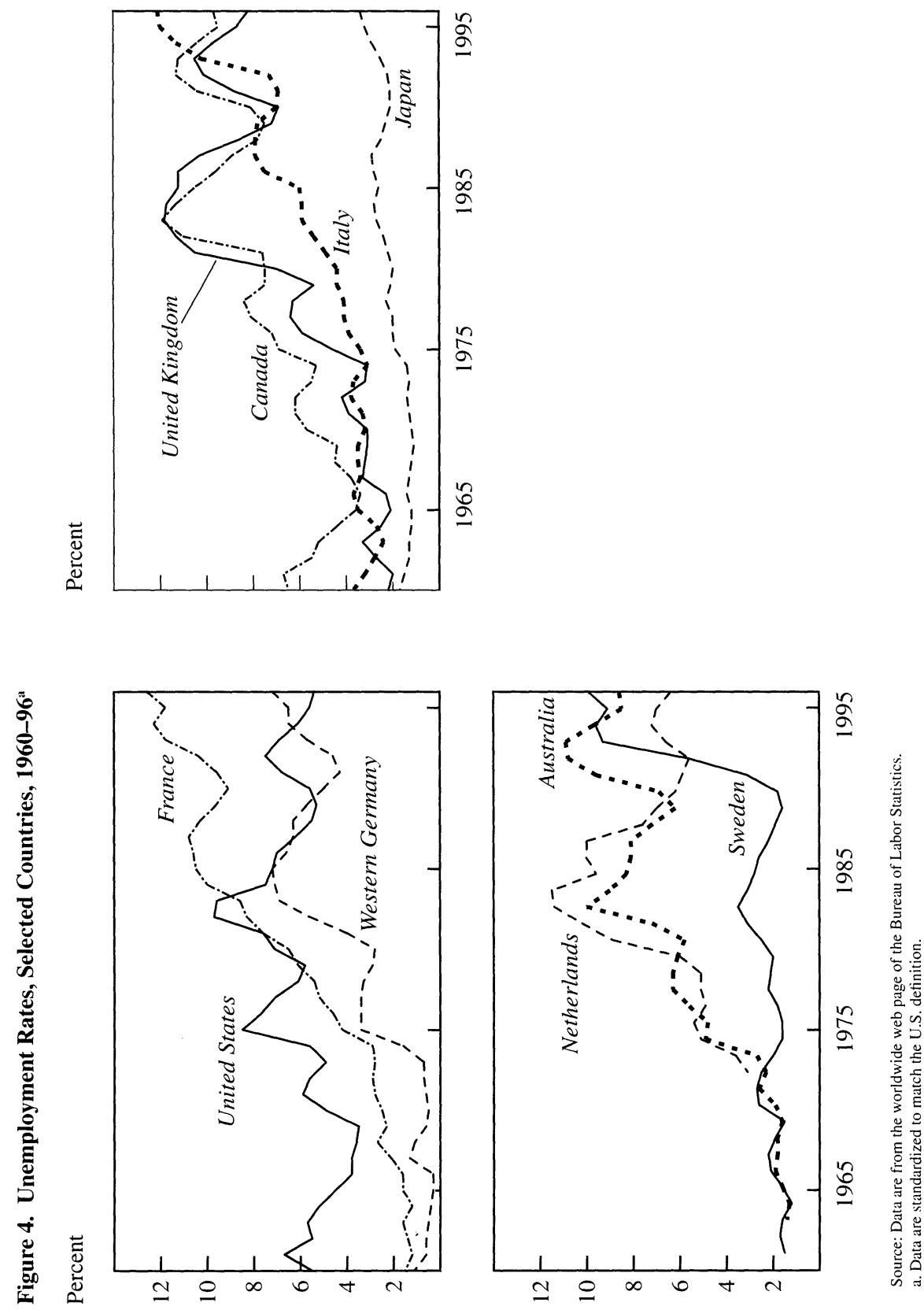
Figure 4 shows BLS standardized unemployment rates in the countries covered in figure 1. An important difference between American and European unemployment, not reflected in the graphs, is the much shorter duration of unemployment spells in the United States. This is one reason why unemployment has been a higher profile issue in Germany than the United States since the 1980s, despite similar unemployment rates. ${ }^{7}$ Countries in which the principal motivation for reductions in full-time hours, whether initiated by unions or government, has been work-sharing — and hence unemployment-include Austria, Belgium (where government initiatives were mostly unsuccessful), Denmark, Finland, France, Germany, and the Netherlands. Australia, Canada, the United Kingdom, and the United States have not undertaken significant cuts in hours in the name of work-sharing, despite high unemployment in some cases; while in Norway, Sweden, Switzerland, and Japan, low unemployment rates have made the debate less relevant until recently.

\section{Work-Sharing in Three Countries}

In this section, I describe work-sharing arrangements in the United States, France, and Germany.

\section{The United States}

Work-sharing in the United States during the past twenty-five years is quickly summarized, since the idea has attracted little interest. Although it is still a topic of interest to unions, the reduction of hours is not a high priority and is not linked to concerns about unemployment. Furthermore, union influence has steadily declined over this periodmembership fell from 27.3 percent of nonfarm workers in 1970 to 16.7 percent in 1995-and bargaining has always been very decentralized. ${ }^{8}$ The worldwide web page of the AFL-CIO, the umbrella organization for the unions, discusses hours under the rubric of alternative work schedules. A shorter work week with full wage compensation (that is,

velopment, Employment Outlook, various issues. The levels are not fully comparable across countries.

7. Note also that the official German rates overstate "unemployment" with respect to the BLS and the closely related International Labour Organisation concepts.

8. For union membership, see Blanchflower (1996). 
no loss in weekly pay) is eighth on the list of strategies for improving the quality of life, but in the example given the employer is a union local. A shorter work week with less than full compensation is noted as a possibility for avoiding layoffs, but the example given is of an employer in Canada.

The only legislation or institution with important implications for work-sharing in the United States is a provision of the Fair Labor Standards Act, introduced in 1940, that mandates an overtime premium of 50 percent. This provision originally covered only 20 percent of workers, but by 1979 it covered 74 percent of nonsupervisory personnel, and in 1985 it was further extended to state and local government employees. ${ }^{9}$ The standard work week associated with this premium has remained at forty hours since its introduction. The motivation of this legislation is work-sharing: to reduce hours per worker by deterring employers from using overtime, hence leading them to increase employment.

\section{Germany}

In the case of Germany, work-sharing must be understood in the context of labor relations. Union membership stood at 33 percent in 1993, the same proportion as in 1970, but the terms of union settlements covered about 90 percent, as conditions negotiated by the unions are extended to nonmembers. ${ }^{10}$ German unions bargain at the regional industry level, but within an industry, agreements across regions are very similar-in many cases, identical. Since World War II, two unions have spearheaded drives to reduce standard hours for full-time workers: the 4 million member union for metal working and related industries, IG Metall, and the printing union, IG Druck. Reduced hours have typically been obtained in these sectors first, and then spread to others.

A wave of hours reductions that began in the 1960s and continued into the early 1970s led, by the mid-1970s, to convergence across industries to a forty-hour standard week with six weeks of vacation. This remained the norm for about ten years, as is indicated in figure 1 by the stability of annual hours during this period. In the climate of low unemployment that existed at the time, the motivation for the reductions

9. Rosenberg (1994).

10. For membership and coverage, see Blanchflower (1996). 
was quality of life. In 1982-83 IG Metall resumed a campaign, initiated in 1978 , for a reduction in the work week to below forty hours and was successful in 1984, after a lengthy strike. The 38.5-hour week was introduced in the metal-working and printing industries in 1985. In the 1980s the ostensible motivation for reductions in hours was quite different: to reduce unemployment, which had risen greatly in Germany.

Reductions in standard hours spread to other sectors, including services. Typically, negotiations led to a multiyear agreement on stepwise reductions in hours, while monthly wages continued to be bargained over each year. The unions usually claimed to have achieved their aim of "full wage compensation," commonly demanded by European unions in work-sharing campaigns. The exact meaning of the term is open to debate, but at a minimum it means that in the short run, the nominal hourly wage should rise enough to offset the decline in hours, keeping monthly pay the same. IG Metall, still in the vanguard, successfully completed its last set of reductions in 1995, when the standard work week was cut to thirty-five hours. The union has now set its sights on a thirty-two-hour week.

German employers have resisted the reductions in standard hours, claiming that they diminish competitiveness in international markets. This is still the position of the umbrella organization for the employers' federations, the Bundesvereinigung der Deutschen Arbeitgeberverbände. ${ }^{11}$ Employers' compensation for the reductions has been increased flexibility in the use of hours. In some cases, for example, standard hours no longer have to be spread evenly over each day of the week to avoid overtime payments, but can vary from week to week, as long as they average to the agreed weekly standard hours over a window of some months. The union contracts allow these flexibility provisions to be introduced at the plant level, subject to agreement by the plant's works council, but surveys find that few firms have adopted them. ${ }^{12}$

11. See "Arbeitszeit ist zu kurz und unflexibel" (working time is too short and inflexible) on the worldwide web page of the Bundesvereinigung der Deutschen Arbeitgeberverbände (www.arbeitgeber.de).

12. See Bosch and others (1988); Promberger (1994). For further descriptions of the evolution of hours in Germany, see Bosch $(1990,1993)$. 


\section{France}

In a manner somewhat similar to Germany, France experienced a convergence to the forty-hour week through a series of agreements at the industry level over the period 1968-78. Legislation passed in 1969 set a norm of four weeks of vacation. Rising unemployment coupled with the cessation of hours reductions through industry agreements made work-sharing an issue in the presidential and parliamentary election campaigns of 1981. The resulting socialist government outlined an objective of reducing standard hours to thirty-five per week over five years. This spurred negotiations at the industry level, but little progress was made, due to resistance from employers and divisions among the three national unions, the Conféderation Générale du Travail, the Conféderation Française Démocratique du Travail, and the Force Ouvrière. Therefore in 1982 the government intervened with new legislation that cut standard weekly hours to thirty-nine with full wage compensation, introduced a fifth paid week of vacation, and reduced the retirement age from sixty-five to sixty. Figure 1 indicates a large drop in annual hours for France in 1982.

Within a year, this law had been judged a failure by all parties, apparently because the unemployment rate continued to rise. Critics included both opponents of work-sharing and proponents of variants of work-sharing, for example, with only partial wage compensation. Instead of legislating a further reduction in hours in 1983, Prime Minister Pierre Mauroy merely called on employers and unions to continue to reduce hours. In the following decade, successive governments introduced various incentive plans to get firms to reduce standard hours. These plans typically offered temporary cuts in social security payments to firms that could agree with unions on (usually large) cuts in standard hours and could demonstrate an increase in employment. The response from firms was not large.

Meanwhile, French employers took the offensive in their negotiations with unions, seeking more flexibility in the use of hours, as described for Germany. Unsuccessful in their initial attempts at the industry level, they had some success later in the 1980s at the firm levelwhere unions are weaker or not represented-and agreed to hours reductions in return. ${ }^{13}$

13. For further description of work-sharing in France, see Boulin (1993); Cette and 


\section{Effects of Work-Sharing on Employment, Wages, and Labor Supply}

A very simple model of static labor demand leads to some unambiguous predictions of the effect of standard hours changes. Consider a firm that chooses hours per worker, employment, and the levels of other inputs to maximize profit and takes standard hours, the wage, and the price of other inputs as given. The existence of fixed per worker costs tends to make employers want higher hours, in order to spread these costs over more hours of work. In some countries, however, workers who fall below a threshold in hours are exempt from certain payroll taxes, which makes low hours attractive for the firm. ${ }^{14}$ Moreover, while in some industries high hours might enhance a firm's ability to keep capital equipment from being idle, in other industries this might not be so. Worker fatigue is another factor that might push firms to prefer lower hours. And if low hours per worker permit the introduction of an additional shift, this arrangement might allow equally long or longer use of capital equipment.

Suppose that the firm initially chooses hours per worker greater than standard hours. The overtime hours are subject to a wage premium. If standard hours are exogenously reduced, the firm will experience a scale effect that will tend to reduce demand for all inputs, since more of the hours must be paid at the overtime premium. The firm will also substitute away from labor toward other inputs and away from workers toward hours per worker: the marginal cost of a new worker has risen, because more of the worker's hours are subject to the overtime premium, while the marginal cost of an extra hour of overtime has remained constant. Thus employment and total hours worked fall unambiguously, but the effect on hours per worker is ambiguous.

This simple model is sensitive to small changes. For example, suppose that the overtime premium rises with overtime because long overtime spills into the weekend, when higher premiums must be paid. The effect on employment of reducing standard hours becomes ambiguous,

Taddéi (1997); Fridenson (1993); Gauvin (1994). Tchobanian (1995) discusses worker representation at the firm level.

14. See Organisation for Economic Co-operation and Development, "Flexibility of Working Hours: Latest Trends and Policy Initiatives,' Employment Outlook, 1998 (forthcoming). 
since the direction of substitution between workers and hours becomes unclear. A firm whose optimal hours are below standard hours but which is constrained to choose standard hours will increase employment when standard hours are reduced. Thus even a simple model has ambiguous predictions, particularly for the economy as a whole. ${ }^{15}$

In bringing the model closer to European reality, it is important to endogenize the hourly wage. In union models such as those of Lars Calmfors, Michael Hoel, and George Houpis, when standard hours are cut exogenously the direction of the wage change is ambiguous. ${ }^{16}$ If the reduction makes hours closer to the workers' optimum level, the value of additional leisure may allow the wage to fall. On the other side, forces working to raise the hourly wage include the fact that lower monthly income reduces the disutility of unemployment. Calmfors is the only one to tackle the problem of endogenizing the changes in standard hours, and his model leaves predictions ambiguous.

A much debated issue is whether workers become more productive (controlling for the levels of other inputs) when they work fewer hours. This is very difficult to measure in most settings. Moreover, the effect on employment of a productivity increase following a cut in standard hours is ambiguous, despite the almost universal popular assumption that it would tend to reduce employment. Since this is, in effect, a case of capital-saving technological progress, the familiar ambiguity in the effect of technology on employment applies: a large scale effect or substitution from capital could make the effect positive.

The effects on labor supply depend on whether hours shift toward or away from desired hours and on what happens to the wage. If hours move away from desired hours, workers may quit or take up second jobs. The effect on spousal labor supply will depend on the direction of the wage change and on how spouses interact in household production and consumption.

\section{Empirical Findings for Wages and Employment}

The difficulty with analysis of most cases of reductions in standard hours is that they have taken place at the national level, leaving no

15. See Hart (1987); König and Pohlmeier (1988); Freeman (1998).

16. Calmfors (1985); Hoel (1987); Houpis (1993). See also Booth and Ravallion (1993); Booth and Schiantarelli (1987). 
natural control group and constraining analysts to use time series. A set of papers that uses time series on manufacturing for European countries, including Germany, estimates employment elasticities with respect to standard hours of between -0.2 and -1.0 , and elasticities of actual hours per worker of between 0.8 and $1.1 .{ }^{17}$ However, some time-series studies of Germany and one of Japan find either no employment response or positive elasticities. ${ }^{18}$ Some papers that use British data relying on variation in standard hours across industries also find no employment response. ${ }^{19}$

As for time-series studies of the response of wages, Harmen Lehment's study of Germany implies a positive relation between standard hours and wages, whereas Wolfgang Franz and Werner Smolny's industry-by-industry study of Germany suggest the opposite, as do studies of Scandinavian manufacturing. ${ }^{20}$ For France, analysis of the 1982 reductions in hours is made particularly difficult by other concomitant measures, such as a wage freeze. ${ }^{21}$

For the United States, Stephen Trejo and Daniel Hamermesh find that an increased overtime premium is partially reflected in a lower wage, but that hours worked per week are nevertheless reduced..$^{22}$

The difficulties inherent in studying a nationwide change in standard hours make Germany an attractive country for study. Elsewhere, I use individual-level data from the German Socio-Economic Panel of the Deutsches Institut für Wirtschaftsforschung (the German Institute for Economic Research), as well as a panel of industries, to exploit the cross-sectional variation in reductions in standard hours. ${ }^{23}$ I consider most of these reductions to be exogenous, since for each industry reductions subsequent to the initial one were agreed in advance and could not be renegotiated. I find that cuts in standard hours translated almost one for one into reductions in actual hours per worker. I also find that

17. Hart and Sharot (1978); Faini and Schiantarelli (1985); Franz and König (1986); Wadhwani (1987); DeRegt (1988).

18. See König and Pohlmeier (1987, 1988, 1989); Entorf, König, and Pohlmeier (1992); Brunello (1989).

19. See Hart (1987); Hart and Wilson (1988).

20. Lehment (1991); Franz and Smolny (1994). On Sweden, see Pencavel and Holmlund (1988); Nymoen (1989).

21. See the discussion in Cette and Taddéi (1997, pp. 105-11).

22. Trejo (1991); Hamermesh and Trejo (1997).

23. Hunt (forthcoming). On the German Socio-Economic Panel, see Wagner, Burkhauser, and Behringer (1993). 
when standard hours were reduced by one hour, straight-time real hourly wages rose between 2 and 2.4 percent relative to wages in industries with no reduction in standard hours. Since a one-hour fall from forty hours is equivalent to 2.5 percent, this implies close to full wage compensation. Thus workers in industries affected by worksharing were able to keep pace with the rising real monthly earnings of workers in unaffected industries, and so contributed to even more rapidly rising hourly real wages. Overall real monthly earnings rose by 14 percent over the period 1984-94. ${ }^{24}$ Finally, my results suggest that reductions in standard hours were associated with employment declines, although the magnitudes of these decreases are imprecisely estimated.

\section{Empirical Findings for Labor Supply}

The effect of work-sharing on spousal labor supply has not previously been examined. Since the average hours of women is lower than that of men, and in particular, since women are much more likely to work part time or not at all, it is logical to look for a spousal labor supply response among wives. In light of the result that something close to full wage compensation occurred in Germany, there is unlikely to be a substantial income effect for the wives of men whose standard hours were reduced. If spouses are substitutes in household production, the wives may nevertheless increase their labor supply, whereas if complementarity in leisure is important, the reverse may occur. I test these possibilities with data from the German Socio-Economic Panel, using self-reported standard weekly hours and "average" actual weekly hours for the period 1984-94.

I take a sample of women aged between twenty and fifty-five who have spouses or domestic partners in the same age range. In order to focus in a simple way on the effect of changes in full-time hours, I drop observations where the partner's standard hours per week are less than thirty-five (10 percent). I also drop observations where the partner's standard hours are greater than forty-five-to reduce measurement error, since the maximum standard hours in this period should be forty-and where the partner is self-employed or works in agriculture. This choice of sample avoids most retirements and school-to-work transitions on the part of the woman. The inclusion of domestic partners

24. Institut der Deutschen Wirtschaft (1995). 
Table 2. Effect of Partner's Hours on Probability of Employment of German Women, 1984-94a

\begin{tabular}{|c|c|c|c|c|c|}
\hline \multirow[b]{2}{*}{ Independent variable } & \multirow{2}{*}{$\begin{array}{c}\text { Mean of } \\
\text { independent } \\
\text { variable }\end{array}$} & \multicolumn{4}{|c|}{ Regression method } \\
\hline & & $O L S$ & $O L S$ & $I V^{\mathrm{b}}$ & $O L S$ \\
\hline Partner's standard hours & $\begin{array}{l}39.2 \\
(1.4)\end{array}$ & $\begin{array}{c}0.0008 \\
(0.0027)\end{array}$ & & & $\begin{array}{c}0.0005 \\
(0.0028)\end{array}$ \\
\hline Partner's actual hours & $\begin{array}{l}41.7 \\
(7.5)\end{array}$ & & $\begin{array}{c}0.0017 \\
(0.0004)\end{array}$ & $\begin{array}{c}0.0010 \\
(0.0033)\end{array}$ & \\
\hline Log of partner's hourly wage ${ }^{c}$ & $\begin{array}{c}2.94 \\
(0.38)\end{array}$ & & & & $\begin{array}{r}-0.052 \\
(0.010)\end{array}$ \\
\hline \multicolumn{6}{|l|}{ Dummy variable } \\
\hline Child aged 0-1 present & $\begin{array}{c}0.09 \\
(0.28)\end{array}$ & $\begin{array}{c}-0.338 \\
(0.010)\end{array}$ & $\begin{array}{c}-0.338 \\
(0.010)\end{array}$ & $\begin{array}{r}-0.338 \\
(0.011)\end{array}$ & $\begin{array}{r}-0.340 \\
(0.011)\end{array}$ \\
\hline Child aged $2-6$ present & $\begin{array}{c}0.28 \\
(0.45)\end{array}$ & $\begin{aligned}-0.178 \\
(0.008)\end{aligned}$ & $\begin{array}{l}-0.178 \\
(0.008)\end{array}$ & $\begin{array}{l}-0.178 \\
(0.009)\end{array}$ & $\begin{array}{c}-0.177 \\
(0.009)\end{array}$ \\
\hline Child aged 7-11 present & $\begin{array}{c}0.26 \\
(0.44)\end{array}$ & $\begin{array}{r}-0.059 \\
(0.008)\end{array}$ & $\begin{array}{c}-0.059 \\
(0.008)\end{array}$ & $\begin{array}{r}-0.059 \\
(0.008)\end{array}$ & $\begin{array}{r}-0.055 \\
(0.009)\end{array}$ \\
\hline $\begin{array}{l}\text { Domestic partner not } \\
\text { spouse }\end{array}$ & $\begin{array}{c}0.07 \\
(0.26)\end{array}$ & $\begin{array}{c}0.202 \\
(0.019)\end{array}$ & $\begin{array}{c}0.202 \\
(0.019)\end{array}$ & $\begin{array}{c}0.202 \\
(0.018)\end{array}$ & $\begin{array}{c}0.206 \\
(0.020)\end{array}$ \\
\hline \multicolumn{6}{|l|}{ Summary statistic } \\
\hline $\bar{R}^{2}$ & & 0.03 & 0.03 & & 0.04 \\
\hline Number of observations & 17,202 & 17,202 & 17,202 & 17,202 & 15,978 \\
\hline Number of individuals ${ }^{d}$ & 3,369 & 3,369 & 3,369 & 3,369 & 3,268 \\
\hline
\end{tabular}

Source: Author's regressions using data from the German Socio-Economic Panel described in Wagner, Burkhauser, and Behringer (1993).

a. Dependent variable is a dummy, set equal to one for women who are employed in a given year $($ mean $=0.53)$. The panel spans the period 1984-94. All specifications include individual fixed effects, women's education dummies and age spline, year dummies, and partner industry dummies. Numbers in parentheses are standard deviations or standard errors.

b. Instrumental variable specification, using partner's standard hours as the instrument for partner's actual hours.

c. Hourly wage is monthly wage divided by $(4.33 \times$ actual weekly hours $)$.

d. Each individual is observed for a number of years.

does not affect the analysis. Table 2 shows results for a fixed effects linear probability analysis of the employment probability of these women. The proportion of women working is 53 percent, so the approximation given by this model will be good. All regressions include information about the presence of children in the household, the age of the woman, the education of the woman, year dummies, whether the woman is married to her partner, and thirty dummies for the partner's industry; not all coefficients are reported.

The first column in table 2 shows some of the means of the sample used. The mean for standard hours of partners is 39.2 , but over the period the mean fell from 40.2 to 38.3 . More descriptive statistics are given below. The second column presents a reduced-form estimate of the effect of the partner's standard hours on the probability of the 
woman working. This estimate is insignificant. I am interested in the effect of changes in partners' actual hours caused by changes in partners' standard hours (the other main cause of change in actual hours is change in overtime hours). This is best captured by a regression including partner actual hours as a covariate, instrumented by partner standard hours. Therefore in the second specification I include partner actual hours rather than partner standard hours, and in the third specification I instrument this with partner standard hours. The coefficient on actual hours in the ordinary least squares (OLS) regression is positive and significant, indicating that a one-hour fall in the partner's actual hours is associated with a fall of 0.0017 in the woman's probability of working - a small effect. Instrumenting causes the standard error to rise, so that the effect is insignificant, as in the reduced-form version of the first column. One therefore cannot confidently attribute to the partner's standard hours an effect on the woman's employment probability: the effect of actual hours in the OLS specification could be identified by changes in overtime, for example.

The final column adds the log of the partner's hourly wage to the covariates. In this regression the sample size is smaller than the sample of the first three columns, where, due to the large number of missings in the wage variable, I do not exclude observations with a missing wage. The hourly wage is computed by dividing monthly earnings by 4.33 times actual weekly hours. Since it is known to have changed as part of the work-sharing program, I prefer specifications that do not include this wage and I omit it in the first three regressions shown. When the wage is included in the instrumental variables specification (not reported), its coefficient is insignificant and the coefficient on actual hours is unchanged. I present instead a reduced-form OLS specification. Here the wage effect is significantly negative and quite large, but it does not affect other coefficients. The sample size is smaller in this regression, since, due to the large number of missings in the wage variable, I do not exclude observations with a missing wage from the sample of the first three columns.

I am interested not only in whether a woman works, but also in her hours. For ease of interpretation, I present in table 3 results of fixed effects on observations only of women with positive hours. When workers with zero hours are included, results of fixed effects on hours are 
Table 3. Effect of Partner's Hours on Hours Worked by German Women with Positive Hours, 1984-94a

\begin{tabular}{|c|c|c|c|c|c|}
\hline \multirow[b]{2}{*}{ Independent variable } & \multirow{2}{*}{$\begin{array}{c}\text { Mean of } \\
\text { independent } \\
\text { variable }\end{array}$} & \multicolumn{4}{|c|}{ Regression method } \\
\hline & & OLS & $O L S$ & $I V^{\mathrm{b}}$ & $O L S$ \\
\hline Partner's standard hours & $\begin{array}{l}39.2 \\
(1.5)\end{array}$ & $\begin{array}{c}0.186 \\
(0.088)\end{array}$ & & & $\begin{array}{c}0.116 \\
(0.089)\end{array}$ \\
\hline Partner's actual hours & $\begin{array}{l}41.8 \\
(6.9)\end{array}$ & & $\begin{array}{c}0.143 \\
(0.015)\end{array}$ & $\begin{array}{c}0.211 \\
(0.096)\end{array}$ & \\
\hline Log of partner's hourly wage ${ }^{c}$ & $\begin{array}{c}2.92 \\
(0.36)\end{array}$ & & & & $\begin{array}{l}-2.75 \\
(0.34)\end{array}$ \\
\hline \multicolumn{6}{|l|}{ Dummy variables } \\
\hline Child aged $0-1$ present & $\begin{array}{c}0.03 \\
(0.16)\end{array}$ & $\begin{array}{c}-3.40 \\
(0.57)\end{array}$ & $\begin{array}{c}-3.49 \\
(0.57)\end{array}$ & $\begin{array}{c}-3.53 \\
(0.65)\end{array}$ & $\begin{array}{r}-3.38 \\
(0.58)\end{array}$ \\
\hline Child aged $2-6$ present & $\begin{array}{c}0.18 \\
(0.39)\end{array}$ & $\begin{array}{c}-6.74 \\
(0.32)\end{array}$ & $\begin{array}{r}-6.68 \\
(0.31)\end{array}$ & $\begin{array}{r}-6.66 \\
(0.34)\end{array}$ & $\begin{array}{r}-6.69 \\
(0.32)\end{array}$ \\
\hline Child aged $7-11$ present & $\begin{array}{c}0.22 \\
(0.41)\end{array}$ & $\begin{array}{l}-3.55 \\
(0.30)\end{array}$ & $\begin{array}{r}-3.50 \\
(0.30)\end{array}$ & $\begin{array}{c}-3.49 \\
(0.29)\end{array}$ & $\begin{array}{c}-3.31 \\
(0.31)\end{array}$ \\
\hline $\begin{array}{l}\text { Domestic partner not } \\
\text { spouse }\end{array}$ & $\begin{array}{c}0.12 \\
(0.32)\end{array}$ & $\begin{array}{c}-0.24 \\
(0.55)\end{array}$ & $\begin{array}{c}-0.23 \\
(0.55)\end{array}$ & $\begin{array}{c}-0.22 \\
(0.49)\end{array}$ & $\begin{array}{c}-0.32 \\
(0.57)\end{array}$ \\
\hline \multicolumn{6}{|l|}{ Summary statistic } \\
\hline Number of observations & 9,055 & 9,055 & 9,055 & 9,055 & 8,440 \\
\hline Number of individuals ${ }^{\mathrm{d}}$ & 2,299 & 2,299 & 2,299 & 2,299 & 2,224 \\
\hline
\end{tabular}

Source: Author's regressions using data from the German Socio-Economic Panel.

a. Dependent variable is average actual weekly hours worked (mean $=31.4)$. The annual panel spans 1984-94 and includes only women who report positive average hours in a given year. All specifications include individual fixed effects, women's education dummies and age spline, year dummies, and partner industry dummies. Numbers in parentheses are standard deviations or standard errors.

b. Instrumental variable specification, using partner's standard hours as the instrument for partner's actual hours.

c. Hourly wage is monthly wage divided by $(4.33 \times$ actual weekly hours $)$.

d. Each individual is observed for a number of years.

very similar in magnitude and significance, while tobit results (without fixed effects) yield significant coefficients of the same signs.

The specifications of table 3 differ from those in table 2 only in the dependent variable. The first column presents means, while the second shows that including the partner's standard hours directly in the regression suggests that a one-hour reduction in the partner's standard hours produces a statistically significant reduction of 0.19 hours for the woman. If instead the partner's actual hours are included the coefficient is more significant. The instrumental variables results from the third equation suggest that a one-hour reduction in the partner's actual hours is associated with a 0.21 -hour reduction in the woman's actual hours; this effect is significant too. 
When the wage is included in the instrumental variables specification (not reported), its coefficient and the coefficient on partner actual hours are both insignificant. When the wage is included in the OLS specification, as reported in the final column, its coefficient is negative and significant, while the coefficient on partner standard hours falls, although not significantly. Most of this fall is due to the inclusion of the wage rather than to the reduction in the sample size.

Reductions in the standard hours of full-time male workers seem thus to have had no effect on the employment rate of women, but to have lowered somewhat the hours of women who do work. Regression results not reported indicate that the magnitude of this hours response is smaller for women with small children and also for women with a university education.

I have also used the German Socio-Economic Panel data to examine the effect of standard hours on the probability of having a second job, using both a linear probability model with fixed effects and a fixed effects conditional logit model. I use the same sample as in the analysis of desired hours below. The effect is insignificant, but given that only 2.5 percent of the sample hold a second job, it is likely that any effect would be very small in comparison with the sample size. I therefore do not report these results here (they are available on request).

\section{Explanations for Differences in Full-Time Hours}

Hours may differ across countries either because the desired hours of employers or workers differ, or because the ability of employers or workers to obtain their desired hours varies. From industrial relations accounts, it would appear that if employers' desired hours are falling, they are doing so more slowly than those of workers, since the drive for lower hours is generally led by unions and resisted by employers.

\section{Institutional Differences}

If it is assumed that workers generally desire shorter hours, the relative strengths of employers and unions across countries will play a role in the evolution of hours. The OECD reports that for a set of eleven countries for which data are available, the correlation between trade 
union density and changes in annual hours between the most recent cyclical troughs in each is $-0.43 .^{25}$

Bell offers some reasons for the different fortunes of work-sharing in the United States and Europe. ${ }^{26}$ In the United States unemployment is only a cyclical-as opposed to a permanent-cause of concern, and unemployment spells are shorter. Unions are weak and decentralized, and the government intervenes little in the labor market on issues related to work hours. Besides, Americans may want to work more hours than do Europeans, even apart from unemployment considerations.

The differences between Germany, where reductions in full-time hours have been carried the furthest, and France, where reductions have been between those of Germany and those of the United States, are more subtle but also appear to be importantly related to union strength. In France, union membership fell from 22 percent in 1970 to 9 percent in 1992, although, as in Germany, coverage is about 90 percent. ${ }^{27}$ French workers do not have one voice speaking for them, at either the industry or the firm levels, but rather they are represented by the three voices of the national unions. These unions have been divided on important aspects of work-sharing, such as at what level of centralization to bargain and whether to establish overtime quotas.

Unemployment rates have been higher in France than in Germany in recent years, so if French unions and workers believe that work-sharing enhances employment, they should have been pushing hard for reduced hours. In fact, the French unions do not seem to have pushed as hard as the German unions. This could reflect realization of their lack of strength, hope that the government would again step in, greater opposition to the necessary flexibility concessions, or desire to work more hours relative to German workers.

The French government's reduction of hours in 1982 may have been more disruptive than reductions arising from negotiation between employers and unions, which, in turn, may have reduced enthusiasm for, or increased opposition to, further reductions. First, the reduction was rather large, once the increased vacation time is taken into account.

25. Organisation for Economic Co-operation and Development, "Flexibility of Working Hours: Latest Trends and Policy Initiatives,' Employment Outlook, 1998 (forthcoming).

26. Bell (1995).

27. Blanchflower (1996). 
Second, the same reductions were imposed on all firms and industries. Third, they occurred earlier than if agreements had been reached through employer-union negotiations: in Germany, employers were able to resist reductions in hours until the worst of the recession had passed, whereas in France the reductions were implemented in the middle of the recession. To the extent that success is judged by eyeballing national unemployment statistics, the French effort was doomed to be judged a failure, while the German program had a much better chance of appearing to succeed.

\section{Determinants of Desired Hours}

Since industrial composition varies across the countries under discussion, employers' desired hours could vary for technological reasons. Within-industry technology probably differs little across rich countries, but desired hours for the same industry might differ across countries due to variation in fixed costs per worker. Payroll tax rates vary across countries. As important as the level of the tax, though, is the maximum earnings for contribution purposes, which determines the fraction of workers for which the payroll tax is a fixed cost. The BLS reports social insurance expenditures and other labor taxes as a percent of hourly compensation costs for production workers in manufacturing. ${ }^{28}$ For 1996 these figures were 21.4 percent in the United States, 24.9 percent in western Germany, and 31.1 percent in France. The lowest thresholds for a large payroll tax in these countries were $\$ 32,181$ for the old-age pension in France (an 8.2 percent payroll tax) and $\$ 49,037$ for the 6.8 percent health insurance payroll tax in Germany. ${ }^{29}$ This suggests that French employers might have the greatest incentive to resist reductions in hours.

The structure of overtime premiums will also influence the employer's trade-off between hours and workers. In the United States the premium is legislated at 50 percent, while in France it is legislated at 25 percent for the first eight hours per week and 50 percent thereafter. In Germany premiums are bargained at the industry level and are typi-

28. These data are available on the worldwide web page of the Bureau of Labor Statistics.

29. I use current exchange rates from the BLS to convert thresholds reported in U.S. Social Security Administration (1997). 
cally set at 25 percent for weekday overtime, although in some industries the premium rises with the number of hours of overtime. Based on these considerations alone, one would expect there to be less overtime in the United States.

Simple support for the idea that workers in different countries desire different hours comes from Bell and Freeman's tabulation of responses to the International Social Survey Program's (ISSP) question on this subject. ${ }^{30}$ The ISSP asks working respondents (including part-time workers) whether they would prefer to stay with their current hours and pay, work more hours for more pay, or work less for less pay. Despite the fact that Americans already work more hours and Germans work fewer, 33 percent of American respondents wanted to work more and only 6 percent wanted to work less in 1989, while only 13.5 of German respondents wanted to work more and 10.1 percent wanted to work less. In linking these results with work-sharing, however, the issue of wage compensation should be considered. The evidence that hourly wages in Germany rose enough to offset reduced hours has been discussed above. Thus work-sharing should be seen as choosing a new wage-leisure bundle, rather than choosing leisure conditional on the wage, as is implicit in the ISSP question.

Bell and Freeman hypothesize that workers in different countries may desire different hours due to different distributions of wages. ${ }^{31}$ Their theory is based on the idea that although an extra hour of work may move individuals in different countries a similar number of percentiles up the earnings distribution, the payoff to that move differs. High earnings inequality implies a larger monetary gain to a given percentile climb, and hence a greater incentive to increase hours. They assemble intriguing evidence that links annual hours of full-time workers (and all workers) with wage inequality, using ISSP data pooled for 1985-89. This link holds promise for explaining recent trends, as the United States was the only rich country with rising wage inequality in the 1970s, and since 1980, Britain alone has surpassed the United States in the growth of inequality. ${ }^{32}$ By contrast, they do not find support for

30. Bell and Freeman (1995) describe the ISSP as a collaborative program involving research institutes that conduct annual surveys of social attitudes and values in different countries. Note that their sample does not include France.

31. Bell and Freeman (1995, 1996).

32. See Katz, Loveman, and Blanchflower (1995); Gottschalk and Smeeding (1997). 
the hypothesis that countries with higher wage levels have lower hours; that is, the income effect story.

\section{Desired Hours in Germany}

Information on desired hours from the German Socio-Economic Panel may be used to assess the extent to which desired and actual hours have converged in Germany. If the hourly wage were not changing, closer alignment of actual and desired hours would indicate higher utility of workers and would lend support to the hypothesis that hours are falling because workers desire to work fewer hours. An alternative hypothesis would be that although most workers do not desire to work fewer hours, they have not opposed union leaders acting in the interest of those most likely to be laid off in the absence of work-sharing. The fact that the real hourly wage is changing, however, complicates the interpretation. Work-sharing has reduced the hours of affected German workers and at the same time has allowed their real monthly earnings to grow as rapidly as those of unaffected workers, which presumably means that it has raised their utility. A larger gap between actual and desired hours could be consistent with this if the union objective were in fact to increase the hourly wage, which could only be achieved if disguised as a work-sharing measure.

I use a sample of workers reporting standard hours of at least thirtyfive per week (full time) and no more than forty-five. I exclude young workers (those under eighteen), apprentices, the self-employed, and agricultural workers. I distinguish between manufacturing and services, and between salaried workers and those who are paid by the hour. The survey asks working respondents how many hours per week they would like to work, recognizing that increasing or decreasing their hours will affect earnings " correspondingly.' I use data for the period from 1985 (the first year in which the question was asked) through 1994.

Table 4 shows how standard, actual and desired weekly hours evolved between 1985 and 1994 for different types of worker. ${ }^{33}$ Stan-

33. Sample weights are used in both tables 4 and 5. This weighting makes considerable difference to the desired hours, since foreigners, who are oversampled, want to work more than natives. A number of workers in the sample report actual hours below twenty or even ten for 1985-89, but there are no such observations over 1990-94. For the purposes of comparing the means only, I drop observations with actual hours of less than eighteen. 
Table 4. Average Standard, Actual, and Desired Hours in Germany, by Type of Worker, 1985 and 1994"

Hours per week

\begin{tabular}{|c|c|c|c|c|c|c|c|}
\hline \multirow[b]{2}{*}{ Worker type } & \multirow[b]{2}{*}{ Year } & \multirow[b]{2}{*}{ Standard } & \multirow[b]{2}{*}{ Actual } & \multirow[b]{2}{*}{ Desired } & \multicolumn{2}{|c|}{$\begin{array}{c}\text { Actual less } \\
\text { desired }\end{array}$} & \multirow[b]{2}{*}{$\begin{array}{c}\text { Sample } \\
\text { size }\end{array}$} \\
\hline & & & & & Value & $\begin{array}{c}\text { Absolute } \\
\text { value }\end{array}$ & \\
\hline \multicolumn{8}{|l|}{ Paid hourly } \\
\hline \multirow[t]{2}{*}{ Manufacturing } & 1985 & $\begin{array}{c}40.0 \\
(1.1)\end{array}$ & $\begin{array}{c}42.5 \\
(4.5)\end{array}$ & $\begin{array}{c}38.5 \\
(7.0)\end{array}$ & $\begin{array}{c}4.0 \\
(8.1)\end{array}$ & $\begin{array}{c}5.1 \\
(7.5)\end{array}$ & 1316 \\
\hline & 1994 & $\begin{array}{l}37.9 \\
(1.5)\end{array}$ & $\begin{array}{c}40.5 \\
(5.3)\end{array}$ & $\begin{array}{l}37.9 \\
(4.9)\end{array}$ & $\begin{array}{c}2.5 \\
(6.1)\end{array}$ & $\begin{array}{c}3.9 \\
(5.4)\end{array}$ & 944 \\
\hline \multirow[t]{2}{*}{ Services } & 1985 & $\begin{array}{l}40.0 \\
(1.2)\end{array}$ & $\begin{array}{c}42.8 \\
(5.2)\end{array}$ & $\begin{array}{c}37.4 \\
(9.5)\end{array}$ & $\begin{array}{c}5.4 \\
(9.9)\end{array}$ & $\begin{array}{c}6.9 \\
(8.9)\end{array}$ & 316 \\
\hline & 1994 & $\begin{array}{c}38.8 \\
(1.5)\end{array}$ & $\begin{array}{c}41.1 \\
(4.3)\end{array}$ & $\begin{array}{c}37.9 \\
(6.7)\end{array}$ & $\begin{array}{c}3.2 \\
(7.7)\end{array}$ & $\begin{array}{c}4.7 \\
(6.8)\end{array}$ & 208 \\
\hline \multicolumn{8}{|l|}{ Salaried } \\
\hline \multirow[t]{2}{*}{ Manufacturing } & 1985 & $\begin{array}{c}39.9 \\
(0.9)\end{array}$ & $\begin{array}{l}44.1 \\
(6.3)\end{array}$ & $\begin{array}{l}37.6 \\
(7.0)\end{array}$ & $\begin{array}{c}6.5 \\
(8.8)\end{array}$ & $\begin{array}{c}7.6 \\
(7.8)\end{array}$ & 366 \\
\hline & 1994 & $\begin{array}{c}37.9 \\
(1.5)\end{array}$ & $\begin{array}{c}42.3 \\
(5.1)\end{array}$ & $\begin{array}{c}38.4 \\
(5.8)\end{array}$ & $\begin{array}{c}3.9 \\
(6.6)\end{array}$ & $\begin{array}{c}5.3 \\
(5.5)\end{array}$ & 362 \\
\hline \multirow[t]{2}{*}{ Services } & 1985 & $\begin{array}{c}40.0 \\
(0.9)\end{array}$ & $\begin{array}{c}42.6 \\
(5.4)\end{array}$ & $\begin{array}{l}35.5 \\
(7.7)\end{array}$ & $\begin{array}{c}7.1 \\
(8.5)\end{array}$ & $\begin{array}{c}7.4 \\
(8.9)\end{array}$ & 667 \\
\hline & 1994 & $\begin{array}{c}38.5 \\
(1.1)\end{array}$ & $\begin{array}{c}41.8 \\
(5.3)\end{array}$ & $\begin{array}{l}36.1 \\
(5.9)\end{array}$ & $\begin{array}{c}5.7 \\
(6.7)\end{array}$ & $\begin{array}{c}6.2 \\
(6.3)\end{array}$ & 667 \\
\hline
\end{tabular}

Source: Author's calculations using data from the German Socio-Economic Panel

a. Sample weights are used. Sample excludes workers reporting fewer than eighteen average actual weekly hours. Standard deviations are in parentheses.

dard hours stood at forty in 1985 and fell by two hours in manufacturing and somewhat less in services. Actual hours are higher, on average, than standard hours and also fell by about two hours in manufacturing. In services actual hours fell by more than did standard hours for hourly paid workers, whereas for salaried workers, actual hours fell by less than did standard hours. Desired hours fell by 0.6 hours for hourly paid workers in manufacturing, but rose for other workers. The difference between actual and desired hours decreased for all types of worker, but the absolute value of this difference is a better proxy for workers' satisfaction with their hours. The absolute value of the difference fell for all types of worker, but by less than the difference.

Table 5 shows the proportions of respondents whose desired hours are less than, the same as, and greater than their actual hours. I consider 
Table 5. Proportions of German Workers Desiring to Work More Than, the Same as, and Less Than Their Actual Hours, 1985 and 1994a

Percent

\begin{tabular}{|c|c|c|c|c|c|}
\hline \multirow[b]{2}{*}{ Worker type } & \multirow[b]{2}{*}{ Year } & \multicolumn{3}{|c|}{ Desired hours } & \multirow[b]{2}{*}{ Sample size } \\
\hline & & More & Same & Less & \\
\hline Salaried, services & $\begin{array}{l}1985 \\
1994\end{array}$ & $\begin{array}{l}5.6 \\
7.5\end{array}$ & $\begin{array}{l}28.8 \\
22.0\end{array}$ & $\begin{array}{l}65.7 \\
70.5\end{array}$ & $\begin{array}{l}687 \\
667\end{array}$ \\
\hline Salaried, manufacturing & $\begin{array}{l}1985 \\
1994\end{array}$ & $\begin{array}{l}12.1 \\
16.5\end{array}$ & $\begin{array}{l}22.8 \\
19.2\end{array}$ & $\begin{array}{l}65.1 \\
64.3\end{array}$ & $\begin{array}{l}386 \\
362\end{array}$ \\
\hline Paid hourly, services & $\begin{array}{l}1985 \\
1994\end{array}$ & $\begin{array}{l}12.2 \\
20.3\end{array}$ & $\begin{array}{l}35.2 \\
32.3\end{array}$ & $\begin{array}{l}52.6 \\
47.4\end{array}$ & $\begin{array}{l}325 \\
208\end{array}$ \\
\hline Paid hourly, manufacturing & $\begin{array}{l}1985 \\
1994\end{array}$ & $\begin{array}{l}12.1 \\
17.4\end{array}$ & $\begin{array}{l}38.7 \\
33.7\end{array}$ & $\begin{array}{l}49.2 \\
48.9\end{array}$ & $\begin{array}{r}1364 \\
944\end{array}$ \\
\hline $\begin{array}{l}\text { By hours worked } \\
\text { Less than } 40\end{array}$ & $\begin{array}{l}1985 \\
1994\end{array}$ & $\begin{array}{l}64.2 \\
28.8\end{array}$ & $\begin{array}{l}14.1 \\
39.0\end{array}$ & $\begin{array}{l}21.8 \\
32.2\end{array}$ & $\begin{array}{l}187 \\
517\end{array}$ \\
\hline Exactly 40 & $\begin{array}{l}1985 \\
1994\end{array}$ & $\begin{array}{l}6.0 \\
3.7\end{array}$ & $\begin{array}{l}69.7 \\
55.5\end{array}$ & $\begin{array}{l}24.3 \\
40.9\end{array}$ & $\begin{array}{l}749 \\
227\end{array}$ \\
\hline More than 40 & $\begin{array}{l}1985 \\
1994\end{array}$ & $\begin{array}{l}7.4 \\
6.2\end{array}$ & $\begin{array}{l}6.1 \\
8.2\end{array}$ & $\begin{array}{l}86.5 \\
85.6\end{array}$ & $\begin{array}{l}428 \\
200\end{array}$ \\
\hline
\end{tabular}

Source: Author's calculations using data from the German Socio-Economic Panel.

a. Sample weights are used.

a worker's actual and desired hours to be the same if the gap between the two is half an hour or less. Breaking down responses by type of worker, the table indicates that large proportions of workers want to work less, larger than are revealed by the International Social Survey Program. ${ }^{34}$ The proportion of workers who want to work less declined between 1985 and 1994, except for salaried services workers. However, for all types of worker, the proportion for whom desired and actual hours are the same fell, and the proportion who want to work more rose. ${ }^{35}$

Table 5 also breaks down further the responses of hourly paid workers in manufacturing, according to whether actual hours are more than, less than, or equal to forty hours per week. In 1985, 64.2 percent of those working less than forty hours wanted to work more, 69.7 percent

34. Bell and Freeman (1995).

35. Many salaried workers receive overtime payment in days off. If they do not include these days off in their calculation of an average week, actual hours may be overstated. This could explain why a higher proportion of salaried workers have actual hours greater than desired hours. 
Table 6. Effect of Standard Hours on Actual and Desired Hours, Germany, 1985-94a

\begin{tabular}{|c|c|c|c|c|}
\hline \multirow[b]{2}{*}{ Dependent variable } & \multicolumn{2}{|c|}{ Hourly paid workers } & \multicolumn{2}{|c|}{ Salaried workers } \\
\hline & Manufacturing & Services & Manufacturing & Services \\
\hline Actual hours & $\begin{array}{c}0.88 \\
(0.05)\end{array}$ & $\begin{array}{c}0.82 \\
(0.12)\end{array}$ & $\begin{array}{c}0.70 \\
(0.11)\end{array}$ & $\begin{array}{c}0.87 \\
(0.08)\end{array}$ \\
\hline Desired hours & $\begin{array}{c}0.29 \\
(0.05)\end{array}$ & $\begin{array}{c}0.44 \\
(0.13)\end{array}$ & $\begin{array}{c}0.32 \\
(0.09)\end{array}$ & $\begin{array}{c}0.25 \\
(0.09)\end{array}$ \\
\hline Actual less desired value & $\begin{array}{c}0.58 \\
(0.07)\end{array}$ & $\begin{array}{c}0.38 \\
(0.16)\end{array}$ & $\begin{array}{c}0.38 \\
(0.14)\end{array}$ & $\begin{array}{c}0.62 \\
(0.12)\end{array}$ \\
\hline Absolute value & $\begin{array}{c}0.25 \\
(0.06)\end{array}$ & $\begin{array}{c}0.38 \\
(0.14)\end{array}$ & $\begin{array}{c}0.48 \\
(0.12)\end{array}$ & $\begin{array}{c}0.63 \\
(0.11)\end{array}$ \\
\hline Summary statistic & & & & \\
\hline Number of observations & 12,828 & 2,748 & 3,938 & 6,994 \\
\hline Number of individuals ${ }^{\mathrm{b}}$ & 2,859 & 981 & 1,078 & 1,971 \\
\hline
\end{tabular}

Source: Author's regressions using data from the German Socio-Economic Panel.

a. For each dependent variable and type of worker, table reports the coefficient on standard weekly hours from a regression equation that also includes individual fixed effects, year dummies, firm size dummies, and industry dummies as regressors. The panel spans $1985-94$. Standard errors are in parentheses.

b. Each individual is observed for a number of years.

of those working forty hours wanted to work that amount, and 86.5 percent of those working more than forty hours wanted to work less, a strong indication of consensus on the desirability of a forty-hour work week. By 1994, when many more of them worked less than forty hours, these workers were much more divided on satisfaction with actual hours. The proportion of workers at forty hours who wanted to work less increased, compared with 1985, but the proportion of workers working more than forty hours who wanted to work less remained constant at around 86 percent.

Since the tool used to achieve work-sharing in Germany has been a reduction in standard hours, I run regressions to see how standard hours affect actual hours, desired hours, and the gap between the two, for different types of worker. The estimation is performed using fixed effects, and the regressions include year dummies, firm size dummies, and industry dummies, in addition to standard hours. Table 6 reports the coefficients on standard hours from the various regressions. The results in the top row imply that when standard hours are reduced by one hour, actual hours are reduced by close to an hour. Thus firms do not increase overtime much in response to the cut in standard hours. ${ }^{36}$

36. These results confirm those presented in Hunt (forthcoming). However, that sample includes 1984 , which changes somewhat the coefficient for hourly paid workers in services. 
The second row examines the effect of standard hours on desired hours. If the wage had not changed when standard hours changed, one would not expect desired hours to change. The regressions presented do not control for the wage. A one-hour reduction in standard hours is found to reduce desired hours by between 0.25 and 0.44 hours. In this and other regressions, it would be interesting to control for the hourly wage. However, only the monthly wage is available, and actual hours per week is the only variable that one has for the conversion to hourly wages. An hourly wage constructed in this way cannot be used in a regression with actual hours on the left-hand side, as it will be correlated with the error, but it can be used in the desired hours regressions. I expected that the coefficient on standard hours might become insignificant when the hourly wage is controlled for, but instead the wage is insignificant for all types of worker, and the standard hours coefficient is unchanged (results not reported).

The third row examines the impact of standard hours on the difference between actual and desired hours; that is, the difference between the first two rows. A one-hour reduction in standard hours reduces this difference by 0.38 to 0.62 hours. The fourth row shows the effect of standard hours on the absolute value of this difference. For hourly paid manufacturing workers, but not for others, using the absolute value greatly reduces the coefficient on standard hours, so that a one-hour reduction in standard hours only brings workers 0.25 hours closer to their desired hours. This suggests that standard hours have not been a very effective tool for aligning the desired and actual hours of such workers. The coefficient for salaried workers in services $(0.63)$ is significantly larger than that for hourly paid manufacturing workers, although significantly lower than one. For these workers, standard hours seem to be a stronger tool for alignment.

The weakness of standard hours reductions as a tool for aligning desired and actual hours suggests that either the unions were not successful in their objectives, or that standard hours reductions were principally aimed at achieving employment gains (as claimed) or wage increases.

\section{Conclusion}

A large number of industrialized countries have experienced considerable declines in annual hours per worker since 1960. In those coun- 
tries where unemployment is high, the declared objective of the unions campaigning for lower hours in recent years has been higher employment through work-sharing. There remain wide differences in levels of annual hours across countries. It has not been established that the differences in full-time hours are related to differences in wage levels, but there is evidence linking more hours worked per week to high wage inequality. It also appears that the ability of workers to obtain their desired hours varies according to a country's institutions. Comparison of Germany and France indicates that stronger unions have been instrumental in the more rapid reduction of full-time hours in Germany.

The gap between actual and desired hours in Germany was narrowed by reductions in standard hours, but by less than one for one-considerably less for hourly paid manufacturing workers. This suggests that better alignment of actual and desired hours was not a principal objective of the unions, or else was not successfully obtained. Other possible union objectives are the declared goal of higher employment, or real wage increases. Reductions in standard hours did not in fact lead to higher employment. But real hourly wages rose enough to offset reduced hours, so the utility of workers remaining employed clearly rose. A by-product of the reductions in standard hours of full-time male workers was a small reduction in the hours of their wives, possibly due to complementarity of leisure between spouses. 


\section{Comment and Discussion}

Lawrence F. Katz: Jennifer Hunt has produced an illuminating study that provides a wealth of information on trends in hours of work in the major OECD economies over the past several decades and on what is known about the effects of explicit hours reduction policies. High and persistent unemployment in many OECD countries (in continental Europe, in particular) has reignited interest in work-sharing - that is, reducing hours per worker or encouraging early retirement to "spread around" available work-as a tool for reducing unemployment.

The existing aggregate time-series evidence on the effects of worksharing policies on employment and unemployment is fairly ambiguous. ${ }^{1}$ Hunt attempts to fill the gap with a careful and persuasive empirical analysis of the recent German experience with work-sharing through union-negotiated reductions in the standard work week for fulltime workers. She uses variation across industries in the timing and magnitude of reductions in standard hours to examine the impact of negotiated reductions in the full-time work week on actual hours of full-time workers, wages, employment, spousal labor supply, and the gap between actual and desired hours of work. She presents convincing evidence that these negotiated reductions in standard hours are successful from the point of view of incumbent full-time workers, who gain increased leisure, a movement in hours toward desired hours, and hourly wage increases to prevent a decline in weekly earnings. But she also finds that such work-sharing efforts have been associated with

1. Freeman (1998). 
reduced, rather than increased, employment. Thus her analysis of the German case offers little hope that proposed reductions in the standard work week by the governments of France and Italy will have much payoff in terms of reduced unemployment.

I comment on three aspects of this study: first, the strikingly divergent trends in hours of work between the United States and Europe; second, the conditions under which work-sharing is likely to be effective in reducing unemployment; and third, the interpretation of the German evidence, and the implications of the German experience for understanding the likely impacts of work-sharing policies in other settings.

Hours Trends in the OECD. Figures 1 to 3 carefully document trends in hours of work per worker and hours of work per adult over the past several decades for ten OECD nations. There are substantial declines in hours per worker in almost all of these countries, except the United States. The declines have been particularly large in continental Europe. This pattern, combined with declining employment-to-population ratios in much of Europe, imply enormous divergence in trends in hours per adult between Europe and the United States. Since the early 1960s, hours per adult have declined by about a third in Germany, France, and Italy, but have increased by 10 percent in the United States. Explicit work-sharing initiatives (for example, reductions in the standard work week, increased vacation time, and early retirement schemes) have played an important role in Europe and have been absent from the United States.

But declining hours per worker in Europe are not just a function of the rise of work-sharing plans in times of slow growth and high unemployment. The greatest reductions in hours per worker and hours per adult are observed in the booming, low-unemployment 1960s. Thus relative to Americans, Europeans appear to have taken much more of the fruits of productivity growth in the form of increased off-the-job leisure, for the past thirty years.

The striking differences in patterns of hours per worker in Europe and the United States also raise important issues concerning the comparability of hours measures, both across countries and over time within countries. Recent work by Katherine Abraham, James Spletzer, and Jay Stewart indicates a substantial divergence in trends in hours of work over the past two decades between U.S. household data based on (self- 
reported) usual weekly hours from the Current Population Survey and establishment survey data. ${ }^{2}$ The U.S. household data suggest a rise in weekly hours from the early 1980 s to the early 1990 s, whereas the establishment data indicate some decline. Given the problems in obtaining consistent findings on hours trends in the United States, crosscountry comparisons are likely to encounter more severe difficulties. Abraham, Spletzer, and Stewart also report growing differences in selfreports of usual weekly hours and reports of individuals on hours of work in time-use studies.

There are large differences in the concepts and data collection techniques underlying the hours series for different countries collected by the OECD and utilized by Hunt. Yet accurate measures of trends in hours of work are necessary to understand trends in labor productivity. Conceptual and practical issues in the measurement of hours of work have been much neglected in work on productivity measurement, and research on these issues could have a high payoff. Crucial issues include the possibility that the line between work and leisure hours is becoming increasingly blurred as employment shifts toward more knowledgebased jobs and traditional factory jobs decline. In addition, cultural differences in defining the "spheres" of the workplace and the family could affect reported hours across countries and over time. Also important is the treatment of on-the-job leisure and socializing. As currently measured, an increased tendency to consume the benefits of productivity as on-the-job, as opposed to off-the-job, leisure could show up as a slowdown in productivity growth. Improved timeuse studies that are consistent across countries could greatly enhance knowledge of trends in hours of work and also improve productivity measurement.

Does Work-Sharing Reduce Unemployment? Figures 1 to 4 also suggest that it would be interesting to compare the effects of work-sharing policies since the mid-1980s in Germany and the Netherlands. Germany has experienced a large decline in the employment-to-population ratio, hours per worker, and hours per adult, along with rising unemployment. Work-sharing has taken the form of negotiated reductions in standard hours, with little growth in part-time employment. The Netherlands has also experienced a large decline in hours per worker, but this has been

2. Abraham, Spletzer, and Stewart (1998). 
a result of large increases in part-time employment (from 21 percent of employment in 1983 to 37 percent in 1995) and has been associated with an increase in the employment-to-population ratio, a decline in the unemployment rate, and little change in hours per adult. ${ }^{3}$ The possible differences in the consequences of work-sharing policies in these two countries raise interesting questions concerning the likely impact of work-sharing on employment and unemployment in other settings.

Many individuals believe that cuts in the work week (that is, reductions in working hours per worker) can reduce unemployment. In what has been labeled the lump of output fallacy, most advocates of worksharing implicitly assume that output is held constant in response to a policy effort to reduce hours per worker, so that total hours of work to be done each week are unchanged ${ }^{4}$ Thus a reduction in hours per worker requires an increase in the number of workers to reach the fixed level of output, and hence work-sharing allocates the available work more equitably and reduces unemployment. Under what conditions is work-sharing likely to increase the number of workers employed and reduce unemployment? Hunt points out that the effects of work-sharing on employment are ambiguous and depend on the substitutability of hours and workers in production, the importance of fixed costs of labor (costs that depend on the number of workers rather than on hours per worker, such as some employment benefits and work set-up costs), and how wage bargaining responds to changes in hours.

The best case scenario for advocates of work-sharing posits a production function, $f(h N)$, where $h$ is average hours per worker and $N$ is the number of workers employed, so that hours per worker and numbers employed are perfect substitutes, and hourly wages $(w)$ are constant. This model also assumes that there are no fixed costs of employment, workers are homogeneous, and hours of work can increase indefinitely without fatigue affecting productivity. Firms maximize $f(h N)-w h N$ and thereby set $f^{\prime}=w$. Thus a mandated reduction in $h$ with $w$ held constant will lead to a proportional increase in $N$ to maintain the initial level of total hours worked $(h N)$, where $f^{\prime}=w$. Output remains constant and the elasticity of employment with respect to hours worked per worker is -1 . If the unemployed are less productive, on average, than

3. Organisation for Economic Co-operation and Development, Employment Outlook, 1997, table E.

4. Layard, Nickell, and Jackman (1991). 
the employed, but are perfect substitutes and are paid proportionately less, employment may expand by an even greater fraction than hours per worker are reduced.

But this outcome requires that such a reduction in unemployment does not affect wage bargaining ( $w$ remains constant) and that incumbent workers with bargaining power do not try to offset income lost in hours reductions with increased wages per hour. A reduction in the unemployment rate is likely to increase the bargaining power of incumbent workers and lead to wage increases that reduce the employment gains. Formal models of the natural rate of unemployment (for example, efficiency wage models and bargaining models), in which work effort or bargaining are affected by relative wages and unemployment, in fact imply that wage increases might fully offset the employment gains, so that total hours worked and output are reduced and employment and unemployment remain the same. ${ }^{5}$ Furthermore, if hourly wages rise and labor is viewed as more inflexible, such policies could induce capital substitution for labor - a pattern that appears to have been important in Europe since the 1970s - and potentially lead to outsourcing of employment, perhaps to eastern Europe, with lower wages, greater hours, and increased flexibility. ${ }^{6}$

Imperfect substitution between hours per worker and the number of workers suggests that the employment gains from work-sharing will be smaller than under the assumption of perfect substitution in the lump of output model. Most econometric estimates suggest that hours and bodies are far from perfect substitutes. ${ }^{7}$ Attempts at work-sharing through reductions in standard hours (as in Germany) do not directly control $h$, but they change the weekly hours at which the overtime premium applies. In this case, the effect not only on the number of workers employed but also on actual hours per week becomes more ambiguous.

Two other factors suggest that mandated work-sharing arrangements may have quite limited, or even perverse, effects on employment in many settings. First, different skill groups are likely to be quite imperfect substitutes in employment. Substantial differences exist between the skills of incumbent workers and those of the unemployed-differences of education and training. A skill mismatch between the em-

5. Layard, Nickell, and Jackman (1991).

6. On capital substitution in Europe, see Blanchard (1997).

7. Hamermesh (1993). 
ployed and unemployed implies that poorly targeted work-sharing will be of limited use in expanding employment for the unemployed. In fact, skilled workers could be complements with the unskilled, and hence hours reductions for the skilled could reduce demand for the unskilled.

Second, mandated reductions in hours below incumbent workers' desired hours at going wages could lead the incumbent workers to take second jobs (that is, increase moonlighting) and thereby fail to create many employment opportunities for the unemployed, especially if the employed are more attractive to other employers. Thus work-sharing could simply result in the same employed workers working the same number of hours on multiple jobs, rather than on a single job. This is potentially a realistic scenario in the United States, where the typical employee expresses a desire to work more hours at the current wage. ${ }^{8}$

Thus there are a number of good reasons to believe that mandated work-sharing is unlikely to produce much of a reduction in unemployment. Hunt's analysis of the German experience and Richard Freeman's review of other strands of evidence strongly indicate that worksharing - whether through reductions in standard hours or through early retirement schemes-is not a panacea for unemployment. ${ }^{9}$

The German Experience with Reductions in Standard Hours. Hunt's analysis of union-negotiated reductions in standard hours in Germany indicates that there are substantial benefits for incumbent workers, as intended. While actual hours of work are reduced, incomes are not, because hourly earnings rise in affected industries by the same proportion as weekly hours decline. Actual hours move toward desired hours. And there is some evidence of better coordination of leisure and work between spouses. But there do not appear to be any benefits for the unemployed; in fact, Hunt's best estimates suggest negative effects on employment.

If the goal of work-sharing is interpreted as being to expand employment, the German experience failed, although incumbent workers benefited. An alternative interpretation would be to view reductions in standard hours not as an exogenous, discrete policy tool of the German unions, but as one component of a broader strategy to increase the "total compensation" of their members. According to this second inter-

8. Freeman (1998).

9. Freeman (1998). 
pretation, the German unions have used their bargaining power to increase the hourly earnings of workers in the face of a labor demand constraint: that higher wages imply lower total hours employed, that is, a downward-sloping labor demand curve. In this context, aggressive wage increases require either a reduction in the number of union members employed or reductions in hours worked per employee. The strategy of the unions has been to reduce hours per employee through reductions in the standard work week, rather than to reduce employment. The alternative scenario of large increases in hourly wages without a reduction in the work week could have displaced existing union member employees or prevented an expansion in membership. In fact, worksharing may have been quite successful in preventing employment loss among incumbent union members in Germany. However, it is unclear whether the German experience of negotiated, endogenous reductions in standard hours can provide information about how unions would react to an exogenous government mandate to reduce hours per worker.

Hunt has shown the value of getting inside the black boxes of individual episodes of explicit attempts at work-sharing. One needs analysis of other cases - for example, the movement toward part-time work and early retirement in the Netherlands-to better assess how mandated work-sharing is likely to affect employment. Most of the existing evidence clearly suggests that work-sharing is not a panacea for the problems of unemployment. Much more work is also required on the measurement and collection of data on hours of work, to better understand the apparent differences in the growth of hours per worker among OECD countries, as well as within- and cross-country trends in labor productivity.

General discussion: Richard Cooper was troubled by the focus on standard week hours, saying that in the United States the standard week only applied to manufacturing and some government employment, both sectors that had been losing importance over the past few decades. $\mathrm{He}$ argued that a major difference between some continental countries and the United States is in the flexibility in employment opportunities, for example, in the scheduling and number of hours worked. France and Germany are much more constrained by laws and conventions, so that the potential mismatch between work-leisure preferences and employment opportunities is much greater than in the United States. He also thought that the role of women was a significant factor in explaining 
differences between the United States and the Continent. For example, he believed that the relatively high U.S. participation rate was largely due to the high level of female labor force participation. While agreeing that the U.S. labor market is undoubtedly relatively flexible, Katz noted that according to the Current Population Survey, relatively few Americans claimed to work between twenty and forty hours. Furthermore, almost 60 percent of workers claim to be working exactly forty hours. Benjamin Friedman added that the fraction of the U.S. labor force reported to work part time has varied over time, but it is about the same today as it was twenty-five years ago. Cooper was skeptical of these data, noting that surveys of employers showed that the average work week has been declining gradually. Hunt noted that a paper by Daniel Hamermesh showed that in the United States, people tended to work more at "unpleasant" times of the day than in Germany, indicating a higher degree of flexibility. Christopher Sims commented that this discussion indicated that differences across countries are much more complicated than can be characterized simply by differences in the means. In the absence of richer data, he suggested that it would be helpful to know more about differences in the dispersion of hours, across both countries and time.

David Laibson guessed that individuals' views on desired hours are significantly affected by what others are doing. With the same wage rate and working conditions, individuals will desire to work less if others are working less, and more if others are working more. The expressed desire to work less may be a "keeping up with the Joneses" effect, reflecting not a change in underlying preferences but a response to changes in the standard work week in society. Statements about desired hours may reflect an individual's view of how long the work week should be, assuming that all individuals will be working it. The exact wording of questions about desired hours is therefore important, and even with carefully crafted questions, it may be difficult to interpret differences across countries.

Maurice Obstfeld thought noteworthy the large differences across countries in labor participation rates for older males. Countries with low unemployment, such as Japan and Switzerland, have very high participation rates for older males, which suggests that this group does not desire to substitute leisure for work; reducing their work week may not result in reductions in unemployment. 


\section{References}

Abraham, Katharine G., James R. Spletzer, and Jay C. Stewart. 1998. “Divergent Trends in Alternative Real Wage Series." In Labor Statistics Measurement Issues, edited by John Haltiwanger, Marilyn E. Manser, and Robert Topel. University of Chicago Press (forthcoming).

Bell, Linda. 1995. "Working Time Policy in the U.S.' In A Time for Working, A Time for Living, edited by Reiner Hoffmann and Jean Lapèyre. Düsseldorf, Germany: European Trade Union Institute.

Bell, Linda, and Richard Freeman. 1995. "Why Do Americans and Germans Work Different Hours?' In Institutional Frameworks and Labor Market Performance: Comparative Views on the U.S. and German Economies, edited by Friedrich Buttler and others. Routledge.

. 1996. "Working Hard." Paper prepared for conference on "Changes in Working Time in Canada and the United States." Ottawa, June 13-15.

Blanchard, Olivier J. 1997. “The Medium Run.” BPEA, 2:1997, 89-158.

Blanchflower, David G. 1996. "The Role and Influence of Trade Unions in the OECD.' Unpublished paper. Dartmouth College (September).

Booth, Alison, and Martin Ravallion. 1993. "Employment and Length of the Working Week in a Unionized Economy in Which Hours of Work Influence Productivity.' Economic Record 69(207): 428-36.

$\rightarrow$ Booth, Alison, and Fabio Schiantarelli. 1987. "The Employment Effects of a Shorter Working Week." Economica 54(214): 237-48.

Bosch, Gerhard. 1990. "From 40 to 35 Hours: Reduction and Flexibilisation of the Working Week in the Federal Republic of Germany." International Labour Review 129(5): 611-27.

- 1993. "The Evolution of Working Time in Germany." Futures 25(June): 521-29.

Bosch, Gerhard, and others. 1988. Arbeitszeitverkürzung im Betrieb: Die Umsetzung der 38,5-Stunden-Woche in der Metall-, Druck- und Holzindustrie sowie im Einzelhandel. Köln: Bund-Verlag.

Boulin, Jean-Yves. 1993. "Les Politiques du Temps de Travail en France: La Perte du Sens.' In Le Temps de Travail, edited by Jean-Yves Boulin, Gilbert Cette, and Dominique Taddéi. Paris: Syros.

$\rightarrow$ Brunello, Giorgio. 1989. "The Employment Effects of Shorter Working Hours: An Application to Japanese Data." Economica 56(224): 473-86.

Calmfors, Lars. 1985. "Work Sharing, Employment and Wages." European Economic Review 27(3): 293-309.

Cette, Gilbert, and Dominique Taddéi. 1997. Réduire La Durée de Travail: De la Théorie à la Pratique. Paris: Livre de Poche.

Dawkins, Peter, and Meredith Baker. 1994. "Australia." In Times Are Changing: Working Time in 14 Industrialised Countries, edited by Gerhard Bosch, 
Peter Dawkins, and François Michon. Geneva: International Institute for Labour Studies.

DeRegt, Erik. 1988. "Labor Demand and Standard Working Time in Dutch Manufacturing, 1954-1982." In Employment, Unemployment, and Labor Utilization, edited by Robert A. Hart. Boston: Unwin Hyman.

$\rightarrow$ Entorf, Horst, Heinz König, and Winfried Pohlmeier. 1992. "Labor Utilization and Nonwage Labor Costs in a Disequilibrium Macro Framework." Scandinavian Journal of Economics 94(1): 71-83.

Faini, Riccardo, and Fabio Schiantarelli. 1985. “A Unified Framework for Firms' Decisions: Theoretical Analysis and Empirical Application to Italy, 1970-1980." In Industrial Investment in Europe: Economic Theory and Measurement, edited by D. Weiserbs. Hingham, Mass.: Kluwer Academic.

$\rightarrow$ Franz, Wolfgang, and Heinz König. 1986. "The Nature and Causes of Unemployment in the Federal Republic of Germany since the 1970s: An Empirical Investigation." Economica 53(210(S)): S219-44.

Franz, Wolfgang, and Werner Smolny. 1994. "Sectoral Wage and Price Formation and Working Time in Germany: An Econometric Analysis." Zeitschrift für Wirtschafts- und Sozialwissenschaften 114(4): 507-29.

Freeman, Richard. 1998. "Work-Sharing to Full Employment: Serious Option or Populist Fallacy?" In Generating Jobs: How to Increase Demand for Less-Skilled Workers, edited by Richard Freeman and Peter Gottschalk. New York: Russell Sage Foundation.

Fridenson, Patrick. 1993. "Le Temps de Travail, Enjeu de Luttes Sociales." In Le Temps de Travail, edited by Jean-Yves Boulin, Gilbert Cette, and Dominique Taddéi. Paris: Syros.

Gauvin, Annie. 1994. "France." In Times Are Changing: Working Time in 14 Industrialised Countries, edited by Gerhard Bosch, Peter Dawkins, and François Michon. Geneva: International Institute for Labour Studies.

$\rightarrow$ Gottschalk, Peter, and Timothy M. Smeeding. 1997. "Cross-National Comparisons of Earnings and Income Inequality." Journal of Economic Literature 35(2): 633-87.

Hamermesh, Daniel S. 1993. Labor Demand. Princeton University Press.

Hamermesh, Daniel S., and Stephen J. Trejo. 1997. "The Demand for Hours of Labor: Direct Evidence from California." Working Paper 5973. Cambridge, Mass.: National Bureau of Economic Research (March).

Hart, Robert A. 1987. Working Time and Employment. Boston: Allen and Unwin.

$\rightarrow$ Hart, Robert A., and T. Sharot. 1978. "The Short-Run Demand for Workers and Hours: A Recursive Model." Review of Economic Studies 45(2): 299_ 309.

Hart, Robert A., and Nicholas Wilson. 1988. "The Demand for Workers and Hours: Micro Evidence from the U.K. Metal Working Industry." In Em- 
ployment, Unemployment, and Labor Utilization, edited by Robert A. Hart. Boston: Unwin Hyman.

Hoel, Michael. 1987. "Can Shorter Working Time Reduce Unemployment?" In Unemployment in Europe: Analysis and Policy Issues, edited by Claes Henric Siven. Stockholm: Timbro.

Houpis, George. 1993. "The Effect of Lower Hours of Work on Wages and Employment." Unpublished paper. London School of Economics.

Hunt, Jennifer. Forthcoming. "Has Work-Sharing Worked in Germany?" Quarterly Journal of Economics.

Institut der Deutschen Wirtschaft. 1995. Zahlen zur wirtschaftlichen Entwicklung der Bundesrepublik Deutschland. Köln: Deutscher Instituts Verlag.

Katz, Lawrence F., Gary W. Loveman, and David G. Blanchflower. 1995. "A Comparison of Changes in the Structure of Wages in Four OECD Countries." In Differences and Changes in Wage Structures, edited by Richard B. Freeman and Lawrence F. Katz. University of Chicago Press.

König, Heinz, and Winfried Pohlmeier. 1987. "Arbeitszeit und Beschäftigung: Eine ökonometrische Studie." In Schriftenreihe des Wirtschaftswissenschaftlichen Seminars: Arbeitsmärkte und Beschäftigung, edited by Gottfried Bombach, Bernhard Gahlen and Alfred E. Ott. Tübingen: J. C. B. Mohr.

- 1988. "Employment, Labour Utilization and Procyclical Labour Productivity." Kyklos 41(4): 551-72.

1989. "Worksharing and Factor Prices: A Comparison of Three Flexible Functional Forms for Nonlinear Cost Schemes." Journal of Institutional and Theoretical Economics 145(2): 343-57.

Layard, Richard, Stephen Nickell, and Richard Jackman. 1991. Unemployment and Macroeconomic Performance. Oxford University Press.

Lehment, Harmen. 1991. "Lohnzurückhaltung, Arbeitszeitverkürzung und Beschäftigung. Eine empirische Untersuchung für die Bundesrepublik Deutschland 1973-1990." Die Weltwirtschaft 2: 72-85.

$\rightarrow$ Nymoen, Ragnar. 1989. "Wages and the Length of the Working Day: An Empirical Test Based on Norwegian Quarterly Manufacturing Data." Scandinavian Journal of Economics 91(3): 599-612.

$\rightarrow$ Pencavel, John, and Bertil Holmlund. 1988. "The Determination of Wages, Employment, and Work Hours in an Economy with Centralised WageSetting: Sweden, 1950-83." Economic Journal 98(393): 1105-26.

Promberger, Markus. 1994. "Betriebliche Arbeitszeitpolitik in der Metallindustrie seit 1990."' WSI Mitteilungen 3: 171-80.

Rosenberg, Sam. 1994. “United States of America." In Times Are Changing: Working Time in 14 Industrialised Countries, edited by Gerhard Bosch, Peter Dawkins, and François Michon. Geneva: International Institute for Labour Studies.

Tchobanian, Robert. 1995. "France: From Conflict to Social Dialogue?" In 
Works Councils: Consultation, Representation, and Cooperation in Industrial Relations, edited by Joel Rogers and Wolfgang Streeck. University of Chicago Press.

$\rightarrow$ Trejo, Stephen J. 1991. "The Effects of Overtime Pay Regulation on Worker Compensation."' American Economic Review 81(4): 719-40.

U.S. Social Security Administration. 1997. Social Security Programs Throughout the World.

$\rightarrow$ Wadhwani, Sushil B. 1987. "The Effects of Inflation and Real Wages on Employment.' Economica 54(213): 21-40.

$\rightarrow$ Wagner, Gert G., Richard V. Burkhauser, and Friederike Behringer. 1993. "The English Language Public Use File of the German Socio-Economic Panel.' Journal of Human Resources 28(2): 429-33. 